\title{
CELL DISTRUPTION MIKROALGA SECARA ENZIMATIS DENGAN SELLULASE
}

\author{
Padil $^{1,2, *)}$, Siti Syamsiah ${ }^{2)}$, Muslikhin Hidayat ${ }^{2)}$, dan Rina Sri Kasiamdari ${ }^{3)}$ \\ ${ }^{1)}$ Jurusan Teknik Kimia, Fakultas Teknik Universitas Riau \\ Kampus Bina Widya Jl. HR. Subrantas Km. 12,5 Simpang Panam, Pekanbaru \\ ${ }^{2)}$ Jurusan Teknik Kimia, Fakultas Teknik Universitas Gadjah Mada \\ Jl. Grafika No 2, Sinduadi, Mlati, Kec. Sleman, Daerah Istimewa Yogyakarta \\ ${ }^{3)}$ Laboratorium Sistematika Tumbuhan, Fakultas Biologi Universitas Gadjah Mada \\ Jl. Teknika Selatan, Sekip utara, Daerah Istimewa Yogyakarta \\ ${ }^{*}$ Penulis korespondensi : fadilpps@yahoo.com
}

\begin{abstract}
ENZYMATIC CELL DISRUPTION OF MICROALGAE USING CELLULASE. Micro-algae is one source of potential alternative energy of third generation to be developed as bioethanol raw material. The starch content trapped in Micro-algae cell walls causing the need of cell distruption to release and convert starch into simple glucose before the fermentation process. This study aims to open up the cell walls of Micro-algae and to explore the effect of sellulase enzymes from Aspergillus niger as Micro-algae cell distruption strategy as well as the optimization of process parameters, i.e the concentration of enzyme, temperature, $\mathrm{pH}$, and time which produce the highest glucose yield. The results showed that the highest glucose yield was $82.44 \%(w / w)$ obtained at an enzyme concentration of $30 \%(w / w)$, temperature $45^{\circ} \mathrm{C}, \mathrm{pH}$ of 4.5 at 40 minutes, the amount of Micro-algae as $0.5 \mathrm{~g} / \mathrm{L}$. In general, cell distruption method using sellulase enzyme was proven to be a promising option to open the cell walls of Micro-algae and convert cellulose into simple glucose simultaneously in producing bioethanol.
\end{abstract}

Keywords: bioethanol; cellulose; cell distruption; enzymatic; micro-algae; starch

\begin{abstract}
Abstrak
Mikroalga merupakan salah satu sumber energi alternatif generasi ketiga yang potensial untuk dikembangkan sebagai bahan baku bioetanol. Kandungan pati yang terperangkap dalam dinding sel mikroalga menyebabkan perlunya cell distruption untuk melepaskan sekaligus mengkonversi pati menjadi glukosa sederhana sebelum proses fermentasi. Penelitian ini bertujuan untuk membuka dinding sel mikroalga sekaligus mengeksplorasi pengaruh enzim sellulase dari aspergillus niger sebagai strategi cell distruption mikroalga serta melakukan optimasi parameter proses yaitu konsentrasi enzim, suhu, pH, dan waktu yang memberikan yield glukosa tertinggi. Hasil penelitian menunjukkan bahwa yield glukosa tertinggi adalah $82,44 \%(w / w)$ yang diperoleh pada konsentrasi enzim $30 \%$ (w/w), suhu $45^{\circ} \mathrm{C}$, pH 4,5 pada waktu 40 menit, dengan jumlah mikroalga $0,5 \mathrm{~g} / \mathrm{L}$. Secara umum, metode cell distruption dengan menggunakan enzim sellulase terbukti menjadi pilihan yang menjanjikan untuk membuka dinding sel mikroalga sekaligus mengkonversi selulosa menjadi glukosa sederhana dalam memproduksi bioetanol.
\end{abstract}

Kata kunci: bioetanol; selulosa; cell distruption; enzimatis; mikroalga; pati

How to Cite This Article: Padil, Syamsiah, S., Hidayat, M., dan Kasiamdari, R.S., (2015), Cell Distruption Mikroalga Secara Enzimatis dengan Sellulase, Reaktor, 15(4), 213-217, http://dx.doi.org/10.14710/ reaktor.15.4.213-217

\section{PENDAHULUAN}

Cadangan energi minyak bumi yang bersumber dari energi fosil kecenderungannya dari waktu ke waktu terus menurun, di samping itu penggunaan energi fosil yang berlebihan dapat menyebabkan terjadinya pencemaran lingkuungan dan perubahan iklim (Chen dkk., 2011; Harun dkk., 2010; Ho dkk., 2011; Ho dkk., 2013). Sejumlah negara seperti Brasil, 
Amerika Serikat dan Kanada telah berkomitmen untuk mengembangkan sumber energi alternatif yang dapat diperbaharui, ekonomis dan ramah lingkungan (Mussgnug dkk., 2010; Nigam dan Singh, 2010). Mikroalga dianggap sebagai bahan baku yang berpotensi untuk memproduksi bioetanol (Lee dkk., 2015).

Mikroalga memiliki kemampuan untuk menangkap $\mathrm{CO}_{2}$ selama fotosintesis, sehingga mengurangi konsentrasi emisi gas rumah kaca di lingkungan. Mikroalga memiliki pertumbuhan yang sangat cepat ( $\pm 7-10$ hari). Mikroalga dapat tumbuh pada lahan non produktif seperti gurun, pantai, serta mikroalga juga dapat dibudidayakan dengan menggunakan photobioreaktor skala besar. Mikroalga juga dapat tumbuh pada berbagai limbah sebagai sumber nutrien seperti nitrogen dan fosfor (Chen dkk., 2011; Harun dkk., 2011; John dkk., 2011; Lee dkk., 2015).

Mikroalga seperti Chlorella, Chamydolomonas, Dunaliella, dan Tetraselmis memiliki kandungan karbohidrat $>40 \%$ berat kering, sehingga berpotensi sebagai bahan baku bioetanol. (Lee dkk., 2015; Ho dkk., 2013; John dkk., 2011; Lee dkk., 2015). Karbohidrat yang terkandung dalam mikroalga sebagian besar dalam bentuk pati dan selulosa, dimana pati pada mikroalga terikat dalam dinding sel yang kaku (Chen dkk., 2013; Choi dkk., 2010; Domozych dkk., 2012; Lee dkk., 2015; Libessart dkk., 1995). Hal ini menyebabkan perlunya dilakukan proses pembukaan dinding sel (cell distruption) untuk melepaskan dan mengkonversikan pati menjadi gula sederhana sebelum proses fermentasi dilakukan. (Choi dkk., 2010; Harun dkk., 2011). Adapun komponen utama dari dinding sel sebagian besar spesies mikroalga adalah selulosa dan hemiselulosa (Chen dkk., 2013; Chu dkk., 1982; Harun dkk., 2011).

Cell distruption mikroalga dapat dilakukan secara kimia, enzimatik, mekanik, maupun kombinasi (Ho dkk., 2013; Lee dkk., 2015; Rabelo dkk., 2009). Cell distruption secara kimia prosesnya lebih cepat dan lebih murah dibanding dengan cara enzimatik maupun mekanik. Penggunaan bahan kimia dapat menyebabkan terjadinya dekomposisi gula menjadi komponen lain yang tidak diinginkan pada proses fermentasi seperti furfural. (Harun dkk., 2010; Ho dkk., 2013). Cell distruption secara enzimatik lebih lambat dan lebih mahal dibandingkan dengan proses kimia (Ho dkk., 2013; Lynd dkk., 2002), tetapi proses enzimatik ramah lingkungan dan dapat menghasilkan glukosa dengan kemurnian tinggi tanpa menghasilkan inhibitor pada proses fermentasi. Proses enzimatik dilakukan pada kondisi proses yang rendah baik temperatur maupun tekanan serta tidak adanya masalah korosi. Adapun proses mekanik memerlukan energi yang cukup tinggi. (Balat dkk., 2008; Choi dkk., 2010).

Beberapa penelitian tentang pretreatment dan hidrolisis mikroalga dengan menggunakan enzim telah dilakukan. Proses pretreatment mikroalga Chlamydomonas reinharatii menggunakan enzim $\alpha$ amilase (Termamyl $120 \mathrm{~L}$ ) dan sakarifikasi dengan menggunakan enzim amiloglukosidase (AMG $300 \mathrm{~L}$ ) dengan menggunakan metode hidrolisis dan fermentasi terpisah (SHF). Pada penelitian ini diperoleh $235 \mathrm{mg}$ etanol pada kondisi operasi $1 \mathrm{~g}$ biomassa mikroalga, suhu $90^{\circ} \mathrm{C}, \mathrm{pH} 4,5$, dan waktu 30 menit (Choi dkk., 2010). Penelitian yang dilakukan oleh Ho dkk. (2013) menggunakan mikroalga Chlorella vulgaris FSP-E menghasilkan glukosa 0,461 g/g biomassa.

Penelitian ini bertujuan untuk membuka dinding sel mikroalga sekaligus mengeksplorasi pengaruh enzim sellulase dari aspergillus niger sebagai strategi cell distruption mikroalga serta melakukan optimasi parameter proses yaitu konsentrasi enzim, suhu, $\mathrm{pH}$, dan waktu yang memberikan yield glukosa tertinggi.

\section{METODE PENELITIAN \\ Bahan}

Sellulase dari aspergillus niger 22178, dibeli dari Sigma-Aldrich, Singapura, berbentuk powder dan berwarna putih dengan aktivity $\approx 0,8$ unit per $\mathrm{mg}$ padat. Setiap 0,8 unit sellulase membebaskan 1,0 $\mu$ mol glukosa dari substrat selulosa pada $\mathrm{pH} 4,0-5,0$. D(+)-Glukose merk KgaA 64271 Darmstadt Germany, Acetic acid (glacial) 100\% merk KgaA 64271 Darmstadt Germany yang digunakan dibeli di toko Chemix, Yogyakarta, Indonesia.

Mikroalga yang digunakan pada penelitian ini adalah mikroalga dengan spesies Tetraselmis chuii berbentuk powder yang dibeli dari Balai Besar Pengembangan Budidaya Laut (BBPBL), Propinsi Lampung, Indonesia.

\section{Cell Disruption Secara Enzimatik}

Cell disruption mikroalga dilakukan dengan menggunakan enzim sellulase yang berasal dari aspergillus niger. Pada penelitian ini dilakukan tiga variasi konsentrasi enzim yang berbeda (10-30\% $\mathrm{w} / \mathrm{w})$, dengan massa mikroalga yang tetap $0,5 \mathrm{~g}$. Campuran enzim-mikroalga dimasukkan ke dalam erlemeyer yang berisi $100 \mathrm{~mL}$ larutan buffer dan ditempatkan dalam shaker pada temperatur yang berbeda dengan kisaran $40-60^{\circ} \mathrm{C}$, kisaran $\mathrm{pH} 4,0-5,5$ untuk waktu 60 menit. Sampel diambil untuk setiap interval waktu 10 menit dan segera pisahkan antara padatan dengan larutan menggunakan centrifuge selama 10 menit. Larutan yang telah terpisah dari padatan langsung dipanaskan dalam water batch pada suhu $90^{\circ} \mathrm{C}$ selama 10 menit dengan tujuan untuk menghentikan aktivitas enzim. Sampel disimpan di dalam freezer pada suhu $-30^{\circ} \mathrm{C}$.

\section{Metode Analisis}

Analisa mikroskopis sel mikroalga sebelum dan sesudah cell distruption dilakukan dengan menggunakan mikroskop fluoresence jenis 
AX10SKOP-40 dengan pembesaran 1000 kali. Komposisi mikroalga yang dianalisa adalah selulosa, hemiselulosa, dan Hot Water Soluble (HWS) dengan menggunakan metode Chesson (Datta, 1981).

Analisis glukosa dilakukan dengan menggunakan metode gula reduksi Nelson Somogyi secara spektrofotometri (Sudarmadji dkk., 1997). Kurva standar glukosa dibuat dengan larutan glukosa pada konsentrasi $(0,1 ; 0,2 ; 0,4 ; 0,8 ; 1,0 \mathrm{mg} / \mathrm{L})$. Larutan glukosa diambil $1 \mathrm{~mL}$ dan dicampur dengan 1 mL larutan Nelson. Larutan dipanaskan pada water bath pada suhu $100^{\circ} \mathrm{C}$ selama 20 menit. Larutan didinginkan sampai mencapai suhu kamar, kemudian ditambahkan $1 \mathrm{~mL}$ larutan Arsenomolybdat dan digojog dengan vortex, kemudian ditambahkan aquades $7 \mathrm{~mL}$ dan digojog lagi. Larutan sampel diukur absorbansinya menggunakan spektro UV-VIS RS spectrophotometer, LaboMed, inc dengan $\lambda$ (panjang gelombang) $540 \mathrm{~nm}$. Yield glukosa dihitung dengan menggunakan persamaan sebagai berikut:

$$
\% \text { Yield }=\frac{\text { Konsentrasi glukosa }\left(\frac{\mathrm{g}}{\mathrm{L}}\right) \text { pd berbagai wkt }}{\text { Konsentrasi substrat }\left(\frac{\mathrm{g}}{\mathrm{L}}\right)}
$$

\section{HASIL DAN PEMBAHASAN \\ Komposisi Mikroalga}

Komposisi biokimia mikroalga spesies Tetraselmis chuii disajikan pada Tabel 1. Empat puluh tujuh koma dua persen $(47,2 \%)$ dari berat kering adalah komponen $\alpha$-selulosa, kemudian diikuti dengan hemisellulosa $35,5 \%$ dan komposisi sisanya adalah Hot Water Soluble (HWS) sebesar 17\%, tanpa adanya lignin. Komposisi $\alpha$-selulosa yang cukup tinggi berpotensi sebagai bahan baku untuk memproduksi bioetanol.

Tabel 1. Komposisi mikroalga spesies Tetraselmis chuii

\begin{tabular}{ll}
\multicolumn{2}{c}{ chuil } \\
\hline Komponen & Komposisi (\%w/w) \\
\hline$\alpha$-sellulosa & $47,2 \%$ \\
Hemisellulosa & $35,5 \%$ \\
HWS & $17 \%$ \\
\hline
\end{tabular}

\section{Cell Distruption Mikroalga}

Selain pati, beberapa mikroalga terutama mikroalga hijau terdapat selulosa sebagai karbohidrat pada dinding sel, yang juga dapat digunakan untuk produksi bioetanol (John dkk., 2011). Pati yang ada pada mikroalga terikat dalam dinding sel yang kaku

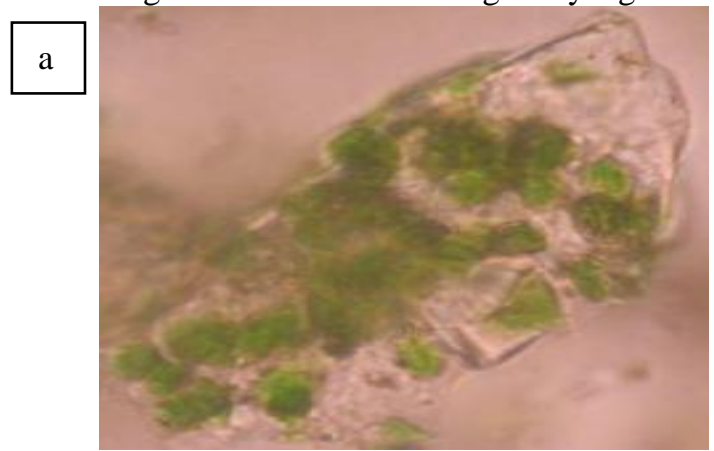

(Chena dkk., 2013; Choi dkk., 2010; Domozych dkk., 2012; Lee dkk., 2015; Libessart dkk., 1995). Pembukaan dinding sel mikroalga bertujuan melepaskan pati sebagai sumber karbon selama proses fermentasi. Gambar mikroskopis dari sel mikroalga sebelum dan setelah cell distruption ditunjukkan pada Gambar 1. Sel-sel mikroalga dalam (b) cell distruption dengan $3 \%(\mathrm{w} / \mathrm{w})$ enzim sellulase selama 40 menit pada $45^{\circ} \mathrm{C}$. Gambar diambil pada $1000 x$ pembesaran. Gambar menunjukkan bahwa sel-sel mikroalga sebelum cell distruption memiliki dinding sel utuh sedangkan sel mikroalga setelah cell distruption telah rusak atau pecah dinding sel.

Sebelum cell distruption dilakukan terlihat bahwa sel-sel mengelompok di dalam plasma sel secara utuh dan sebagian besar berbentuk lonjong. Hal ini menunjukkan bahwa pati terperangkap di dalam sel. Gambar 1b menunjukkan pecahnya dinding sel, hal ini dibuktikan dengan rusaknya plasma sel dan selsel mikroalga. Perubahan dari sel-sel yang utuh menjadi sel-sel yang rusak setelah cell distruption secara enzimatik menunjukkan bahwa enzim sellulase dapat membuka dinding sel mikroalga dan melepaskan pati yang terjebak.

\section{Pengaruh Konsentrasi Enzim}

Untuk mengetahui pengaruh konsentrasi enzim sellulase pada proses cell distruption dilakukan tiga variasi konsentrasi yang berbeda yaitu $10 \%, 20 \%$, dan $30 \%(\mathrm{w} / \mathrm{w})$, dengan waktu tinggal tetap 40 menit, suhu konstan $45^{\circ} \mathrm{C}$, dan konsentrasi mikroalga yang digunakan $5 \mathrm{~g} / \mathrm{L}$. Hasil penelitian disajikan dalam Gambar 2. Gambar 2 menunjukkan bahwa semakin tinggi konsentrasi enzim dan waktu proses, terjadi peningkatan yield glukosa, tetapi peningkatan ini hanya terjadi dari waktu 10-40 menit. Hal ini dapat dijelaskan bahwa semakin besar konsentrasi enzim dengan pertambahan waktu akan menyebabkan aktivitas enzim semakin besar dan semakin cepat reaksi yang dikatalisis enzim serta semakin banyak enzim yang berikatan dengan substrat yang akan menyebabkan semakin banyak kompleks enzimsubstrat yang terbentuk. Maka produk yang terbentukpun akan semakin banyak. Waktu di atas 40 menit menghasilkan yield glukosa tidak terjadi peningkatan yang signifikan, karena setelah selang beberapa waktu, jumlah substrat yang tersedia sudah mulai berkurang.

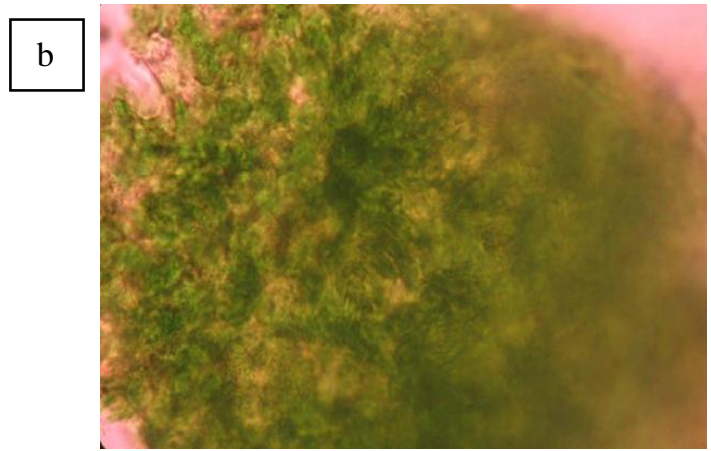




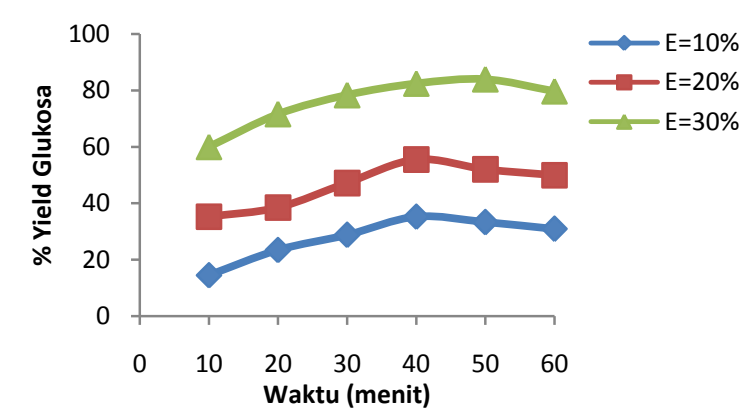

Gambar 2. Yield glukosa dengan konsentrasi enzim yang berbeda untuk powder biomassa yang tetap 5 $\mathrm{g} / \mathrm{L}$, pada suhu $45^{\circ} \mathrm{C}$ dan $\mathrm{pH} 4,5$

Penelitian ini menghasilkan yield glukosa $82,44 \%$, lebih tinggi dibanding penelitian yang dilakukan oleh (Choi dkk., 2010) yang mempelajari pengaruh enzim amilase dari B.licheniformis dan glukoamilase dari aspergilus niger, pada $\mathrm{pH}$ 4,5 dan suhu $55^{\circ} \mathrm{C}$ selama 30 menit dengan konversi glukosa yang diperoleh $0,57 \mathrm{~g}$ glukosa/g biomassa mikroalga. Dalam penelitian lain mikroalga dengan spesies Chlorococum humicola dihidrolisis menggunakan enzim dari Trichoderma reesei, menghasilkan yield glukosanya $64,2 \%$ (w/w) pada suhu $40^{\circ} \mathrm{C}, \mathrm{pH} 4,8$ dan konsentrasi mikroalga $10 \mathrm{~g} / \mathrm{L}$ (Harun dkk., 2011).

\section{Pengaruh pH dan Temperatur Cell Distruption Secara Enzimatik}

Variasi pH yang dilakukan pada cell distruption enzimatik mikroalga spesies Tetraselmis chuii adalah 4,0-5,5 dan hasilnya disajikan pada Gambar 3. $\mathrm{pH}$ optimum yang didapatkan dari penelitian ini adalah kisaran 4,0-4,5, dimana yield glukosa yang tertinggi didapatkan pada $\mathrm{pH} 4,5$. Pada pH 5,0-5,5 yield glukosa yang didapatkan mengalami penurunan, hal ini terjadi karena enzim sellulase akan mengalami perubahan struktur atau muatan asam amino yang merupakan sisi aktif yang berfungsi dalam pengikatan substrat. Hal ini mengakibatkan terganggunya interaksi antara sisi aktif enzim dengan substrat sehingga yield glukosa yang dihasilkan menjadi lebih rendah (Harun dkk., 2011; Shuler dan Kargi, 1991).

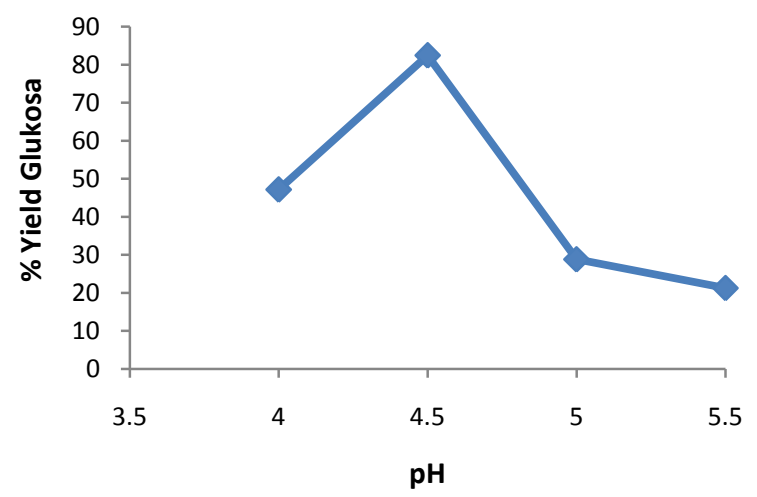

Gambar 3. Pengaruh $\mathrm{pH}$ pada cell distruption enzimatik mikroalga spesies Tetraselmis chuii
Pada penelitian ini juga diamati pengaruh suhu terhadap yield glukosa yang dihasilkan dengan konsentrasi enzim 30\% (w/w) selama 60 menit seperti yang ditampilkan pada Gambar 4. Suhu cell distruption yang optimum adalah $45^{\circ} \mathrm{C}$ dengan yield glukosa $82,44 \%$, sedangkan suhu di atas dan di bawah $45^{\circ} \mathrm{C}$ menghasilkan yield glukosa yang lebih rendah. Aktivitas enzim akan meningkat bersamaan dengan peningkatan suhu proses, laju proses metabolisme akan naik sampai batasan suhu maksimal. Kecepatan reaksi mula-mula meningkat dengan naiknya suhu, hal ini disebabkan oleh peningkatan energi kinetik pada molekul-molekul yang bereaksi, akan tetapi pada akhirnya energi kinetik enzim melampaui rintangan energi untuk memutuskan ikatan hidrogen dan hidrofobik yang lemah, yang mempertahankan struktur sekundertersiernya. Pada suhu ini terjadi denaturasi enzim menunjukkan suhu optimal. Pada umumnya enzim akan bekerja baik pada suhu optimum, yaitu antara 30-50 ${ }^{\circ} \mathrm{C}$ (Harun dkk., 2011; Shuler dan Kargi, 1991).

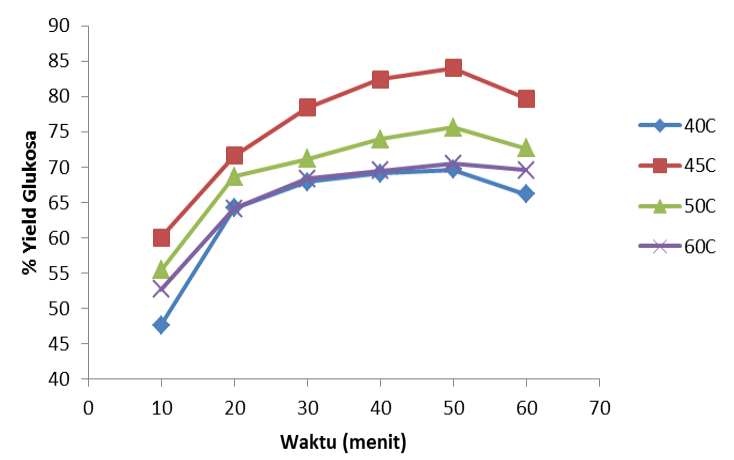

Gambar 4. Yield glukosa dengan suhu yang berbeda untuk powder biomassa yang tetap $5 \mathrm{~g} / \mathrm{L}$, pada konsentrasi enzim $30 \%$ dan $\mathrm{pH} 4,5$

\section{KESIMPULAN}

Hasil penelitian menunjukkan bahwa cell distruption dengan menggunakan enzim sellulase berhasil dilakukan, hal ini dibuktikan dengan rusaknya plasma sel dan sel-sel mikroalga. Proses cell distruption mikroalga sekaligus mengkonversi selulosa menjadi glukosa sederhana dalam memproduksi bioetanol. Yield glukosa tertinggi adalah $82,44 \% \quad(\mathrm{w} / \mathrm{w})$ yang diperoleh pada konsentrasi enzim $30 \%$ (w/w), suhu $45^{\circ} \mathrm{C}$, dan $\mathrm{pH} 4,5$ pada waktu 40 menit dengan jumlah mikroalga 0,5 $\mathrm{g} / \mathrm{L}$.

\section{DAFTAR PUSTAKA}

Balat, M., Balat, H., and Oz, C., (2008), Progress in bioethanol processing, Prog. Energy Combust. Sci., 34, pp. 551-573.

Chen, C.Y., Yeh, K.L., Aisyah, R., Lee, D.J., and Chang, J.S., (2011), Cultivation, photobioreactor design and harvesting of microalgae for biodiesel production: a critical review, Bioresour. Technol. 102, pp. 71-81. 
Chen, C.Y., Zhao, X.Q., Yen, H.W., Ho, S.H., Cheng, C.L., Lee, D.J., Bai, F.W., and Chang, J.S., (2013), Microalgae-based carbohydrates for biofuel production, Biochemical Engineering Journal, 78, pp. 1-10.

Choi, S.P., Nguyen, M.T., and Sim, S.J., (2010), Enzymatic pretreatment of Chlamydomonas reinhardtii biomass for ethanol production, Bioresour. Technol., 101, pp. 5330-5336.

Chu, F.L.E., Dupuy, J.L., and Webb, K.L., (1982), Polysaccharide composition of five algal species used as food for larvae of the American oyster, Crassostrea virginica, Aquaculture, 29, pp. 241-252.

Datta, R., (1981), Acidogenic fermantation of lignocellulose-acid yield and conversion of components, Journal of Biotechnology and Bioengineering, 23 (9), pp. 2167-2170.

Domozych, D.S., Ciancia, M., Fangel, J.U., Mikkelsen, M.D., Ulvskov, P., and Willats, W.G.T., (2012), The cell walls of green algae: a journey through evolution and diversity, Front. Plant Sci., 3, p. 82 .

Harun, R., Danquah, M.K., and Forde, G.M., (2010), Microalgal biomass as a fermentation feedstock for bioethanol production, J. Chem. Technol. Biotechnol., 85, pp, 199-203.

Harun, R., Michael, K., and Danquah, (2011), Enzymatic hydrolysis of microalgal biomass for bioethanol production, Chemical Engineering Journal, 168, pp.1079-1084.

Ho, S.H., Chen, C.Y., Lee, D.J., and Chang, J.S., (2011), Perspectives on microalgal $\mathrm{CO}_{2}$-emission mitigation systems - a review, Biotechnol. Adv., 29, pp. 189-198.

Ho, S.H, Huang, S.W., Chen C.Y., Hasunuma, T., Kondo, A., and Chang, J.S., (2013), Bioethanol production using carbohydrate-rich microalgae biomass as feedstock, Bioresource Technology, 135, pp. 191-198.

John, R.P., Anisha, G.S., and Nampoothiri, M.K., (2011), Ashok Pandey Micro and macroalgal biomass: A renewable source for bioethanol, Bioresource Technology, 102, pp. 186-193

Lee, O.K., Oh, Y.K., and Lee, E.Y., (2015), Bioethanol production from carbohydrate-enriched residual biomass obtained after lipid extraction of Chlorella sp. KR-1, Bioresource Technology, 196, pp. 22-27.

Lee, O.K., Seong, D.H., Lee, C.G., and Lee, E.Y., (2015), Sustainable production of liquid biofuels from renewable microalgae biomass, Journal of Industrial and Engineering Chemistry, 29, pp. 24-31.

Libessart, N., Maddelein, M.L., Koornhuyse, N., Decq, A., Delrue, B., Mouille, G.,D’Hulst, C., and Ball, S., (1995), Storage, photosynthesis and growth: the conditional nature of mutations affecting starch synthesis and structure in Chlamydomonas, Plant Cell, 7, pp. 1117-1127.

Lynd, L.R., Weimer, P.J., van Zyl, and Pretorius W.H., (2002), Microbial cellulose utilization: fundamentals and biotechnology, Microbiol. Mol. Biol. Rev., 66 (3), pp. 506-577.

Mussgnug, J.H., Klassen, V., Schluter, A., and Kruse, O., (2010), Microalgae as substrates for fermentative biogas production in a combined biorefinery concept, J. Biotechnol., 150, pp. 51-56.

Nigam, P.S. and Singh, A., (2010), Production of liquid biofuels from renewable resources, Prog. Energy Combust. Sci., doi:10.1016/j.pecs. 01, p. 003.

Rabelo, S.C, Filho, R.M, and Costa, A.C., (2009), Lime pretreatment of sugarcane bagasse for ethanol production, Appl Biochem Biotechnol, 153, pp.13950 .

Shuler, M.L. and Kargi, F., (1991), Bioprocess Engineering: Basic Concepts, Prentice-Hall College Div., pp 75-78.

Sudarmadji, S., Haryono, B., dan Suhardi. (1997), Prosedur Analisa Untuk Bahan Makanan dan Pertanian, Yogyakarta: Liberty. 